Universal Decimal Classification (UDC) 613.96

\title{
THE FEATURES OF LIFE QUALITY OF TEENAGERS WHO ARE TRAINED IN EDUCATIONAL INSTITUTIONS OF PSKOV CITY
}

\section{E. A. Alekseyeva}

Administration of the Federal Supervision Agency for Consumer's Rights Protection and Human Wellbeing in Pskov region, Russian Federation, Pskov, 21 a, Gogolia St., 180000

The paper presents a comparative analysis of the life quality in school children and vocational students in Pskov. The survey included 382 teenagers aged 14-18 (206 teenagers studying at comprehensive schools, and 176 teenagers studying at vocational schools. The obtained results described the state of wellbeing of the respondents including the physical, psychological and social health. Significant differences were revealed in the quality of life of the two groups indicating a lower standard of living of the second group, regardless their work experience. The PF indicator in school students was 1.19 times higher than in vocational students.

Key words: life quality, secondary school students, pupils of the establishments of primary professional education, teenagers, seniors, physical and psychological health, non-learning employment, working teenagers.

The Pskov Office of the Federal Supervision Agency for Consumer's Rights Protection and Human Wellbeing (hereinafter - the Federal Supervision Agency) in collaboration with the Research Institute for Hygiene and Child Health Protection under the Scientific Center of the Russian Academy of Sciences carried out a survey among high school students and vocational students (studying at research and production educational institution) in Pskov in 2011-2012. The survey results were used to compare the quality of life of the school students and vocational students and improve the approaches to the assessment of the sanitary and epidemiological wellbeing at professional educational institutions for teenagers.

The Pskov Office of the Federal Supervision Agency works to foster the sanitary and epidemiological wellbeing of the local child population, and to mitigate the environmental impact on the health of children and teenagers. It is especially important now that children and teenagers in Russia are involved in labor activities these days. Some young people under 18 have a full-time job, and it is not uncommon for school children to be involved in labor activities in their free time [10]. It is necessary to improve the approaches to and criteria of the assessment of the sanitary and epidemiological wellbeing of the vocational students, and mitigate the impact of the learning environment on the health of teenagers [7]. Previous studies report that the quality of life of students of various institutions differs, and that the living area has an effect on the health of children and teenagers. Overall, it is suggested that the quality of life of school children is better than that of the students at research and production educational facilities $[2-4,9]$. As a result, the latter develop unwillingness to study, limited professional and military aptitude, failure to implement their reproductive potential, and the likelihood of unhealthy children [5]. The basic health risk factors include the sanitary and epidemiological ill-being at the educational institutions, insufficient nutrition, incompliance with the hygienic standards of the school and rest balance, sleep, and time outdoors. The most aggressive factors that impact the health of school children include the study and extracurricular load, intense learning environment, and lack of time to process new information [6]. The following three factors also have a negative impact on children's health: harmful habits sleep deficit, and insufficient physical activity. Harmful hazards are proved to affect the state of health and result in fatigue and increased incidence of illnesses [11].

The above issues determined the purpose of the research: to study the lifestyle and quality of life of high school students and vocational students in Pskov and to assess the impact of socio-hygienic factors on the quality of life and subjective assessment of the state of health.

Materials and Methods. This survey was conducted among 382 young people aged 14-18 including 206 students of $9-11^{\text {th }}$ grades of local 
secondary schools (the total count of $9-11^{\text {th }}$ graders as of the beginning of 2012 school year was 8714) and 176 teenagers studying at research and production educational institutions (the total count of RPEI students was 382). Purposive sampling (specific people were chosen within the population at the time of the study) was used to select the respondents meaning the study was nonrandomized.

In the course of data processing, the quality of life indicators (QLI) were obtained to describe the state of well-being including physical, psychological, and emotional health.

To analyze the QLI, a questionnaire based on MOS-SF-36 survey was used (author - J.E.Ware, 1993 [1]). It was developed by the Research Institute for Hygiene and Child Health Protection under the Scientific Center of the Russian Academy of Sciences. The survey on the quality of life included 11 questions grouped by the following 8 scales:

1. Physical functioning (PF),

2. The role functioning determined by the physical condition (RFP)
3. Intensity of pain (IP)

4. General health $(\mathrm{GH})$

5. Everyday activity (EA)

6. Social functioning (SF)

7. The role functioning determined by the emotional condition (RFE)

8. Mental Health (MH).

The scales can be grouped around the following indicators: "physical health component" and "mental health component".

The data was processed with the help of parametric statistical methods. Statistical significance of the results was assessed using Student's t-test. Data processing was performed using the program Statistica 6.0.

Results. The average QLI in Pskov students were tabulated in a general table (Tables 1,2) which includes 2 groups of teenagers: "School students" and "Vocational students" which are divided in the following subgroups: "All", "Girls", "Boys". Each of the subgroups has three columns: "All", "Employed", and "Unemployed".

Table 1

Assessment results of the quality of life of teenagers using SF-36

\begin{tabular}{|c|c|c|c|c|c|c|c|c|}
\hline \multirow[b]{2}{*}{ Observation group } & \multicolumn{4}{|c|}{ Physical health components } & \multicolumn{4}{|c|}{ Mental health components } \\
\hline & $\mathrm{PF}$ & RFF & IP & $\mathrm{GH}$ & EA & SF & RFE & MH \\
\hline \multicolumn{9}{|c|}{ School students } \\
\hline All $(\mathrm{N}=206$ & $\begin{array}{c}91,8 * \pm 3,6 \\
6\end{array}$ & $71 \pm 6,12$ & $73,9 \pm 3,86$ & $68,8 \pm 3,66$ & $57,6 \pm 3,2$ & $74,8 \pm 3,66$ & $62,8 \pm 3,66$ & $63 \pm 6,52$ \\
\hline $\begin{array}{c}\text { Employed } \\
(\mathrm{N}=93)\end{array}$ & $90,8 \pm 5,48$ & $72,8 \pm 5,48$ & $72,3 \pm 3,45$ & $68 \pm 9,43$ & $57,2 \pm 2,83$ & $74,7 \pm 5,16$ & $64,5 \pm 4,41$ & $61,2 \pm 2,83$ \\
\hline $\begin{array}{l}\text { Unemployed } \\
\qquad(\mathrm{N}=113)\end{array}$ & $92,7 \pm 4,67$ & $69,5 \pm 3,99$ & $75,2 \pm 2,56$ & $69,5 \pm 3,99$ & $58 \pm 9,04$ & $74,9 \pm 5,24$ & $61,4 \pm 3,59$ & $64,6 \pm 4,35$ \\
\hline \multicolumn{9}{|c|}{ Vocational students } \\
\hline All $(\mathrm{N}=176)$ & $77,1 \pm 1,08$ & $73,6 \pm 2,58$ & $74,1 \pm 1,08$ & $67,5 \pm 2,37$ & $62,5 \pm 2,37$ & $75,9 \pm 3,11$ & $68,6 \pm 2,58$ & $66,8 \pm 2,95$ \\
\hline $\begin{array}{l}\text { Employed } \\
(\mathrm{N}=85)\end{array}$ & $77,2 \pm 2,63$ & $69,4 \pm 3,68$ & $72,3 \pm 3,2$ & $68,8 \pm 5,09$ & $63,2 \pm 2,63$ & $74,7 \pm 4,79$ & $71,0 \pm 8,52$ & $68,2 \pm 2,63$ \\
\hline $\begin{array}{l}\text { Unemployed } \\
(\mathrm{T}=91)\end{array}$ & $77,1 \pm 1,79$ & $77,5 \pm 3,91$ & $75,8 \pm 4,87$ & $66,3 \pm 3,06$ & $61,9 \pm 5,14$ & $76,9 \pm 5,14$ & $66,3 \pm 3,06$ & $65,4 \pm 3,52$ \\
\hline
\end{tabular}

$\mathrm{N}$ o t e s: * differences are significant for the same indicators by Student's criterion.

Table 2

Assessment results of the quality of life in girls and boys by SF-36

\begin{tabular}{|c|c|c|c|c|c|c|c|c|}
\hline \multirow{2}{*}{ Observation groups } & \multicolumn{9}{|c|}{ Physical health component } & \multicolumn{4}{c|}{ Mental health component } \\
\cline { 2 - 9 } & PF & RFF & IP & GH & EA & SF & RFE & MH \\
\hline \multicolumn{8}{|c|}{ School students } \\
\hline Girls (N=123) & $90,6 \pm 4,17$ & $63,4 \pm 3,44$ & $71,6 \pm 4,17$ & $65,6 \pm 4,17$ & $54 \pm 8,75$ & $71,4 \pm 3,44$ & $56,6 \pm 4,17$ & $58,7 \pm 4,48$ \\
\hline $\begin{array}{c}\text { Boys } \\
(\mathrm{N}=83)\end{array}$ & $93,6 \pm 5,09$ & $82,2 \pm 3,0$ & $77,3 \pm 3,65$ & $73,6 \pm 5,09$ & $63 \pm 10,34$ & $79,8 \pm 5,81$ & $71,9 \pm 6,31$ & $69,4 \pm 4,2$ \\
\hline \multicolumn{8}{|c|}{ Vocational students } \\
\hline Girls & $74,4 \pm 3,62$ & $71,9 \pm 5,29$ & $75,5 \pm 4,03$ & $63,1 \pm 1,84$ & $56,7 \pm 4,72$ & $72,4 \pm 3,62$ & $66,0 \pm \underline{8}, 76$ & $59,6 \pm 4,39$ \\
\hline
\end{tabular}


The features of life quality of teenagers who are trained in ...

\begin{tabular}{|c|c|c|c|c|c|c|c|c|}
\hline$(\mathrm{N}=83)$ & & & & & & & & \\
\hline $\begin{array}{c}\text { Boys } \\
(\mathrm{N}=89)\end{array}$ & $75,3 \pm 3,11$ & $78,7 \pm 4,65$ & $76,9 \pm 5,21$ & $71,9 \pm 5,21$ & $68,2 \pm 2,55$ & $77,4 \pm 3,57$ & $77,2 \pm 2,55$ & $72,6 \pm 4,33$ \\
\hline
\end{tabular}

$\mathrm{N}$ o t e s: * differences are significant for the same indicators by Student's criterion.

Comparative analysis within the "All" group delivered consistent results on the physical functioning indicators (PF) in school children and vocational students. The PF in school children is 1.19 times higher than that in vocational students. The likely reason for this is the fact that vocational students more frequently live in single-parent homes, large families with many kids, low-income families. Additionally, vocational students are more prone to harmful habits like smoking, alcohol, and drugs.

For example, $11.2 \%$ (23 students) of Pskov school students and $52.3 \%$ (92 students) of vocational students smoke; $2.9 \%$ (6 students) and
$20.5 \%$ (36 students) respectively consume alcohol more than once a month; $2.9 \%$ (6 students) and $15.3 \%$ (27 students) respectively have tried drugs. In other words, there are sufficiently more smokers among vocational students $(\mathrm{OR}=8.7 \pm 0.46 ; \mathrm{CI}=$ $1,0-16,4)$. Also more vocational students consume alcohol more than once a month $(\mathrm{OR}=$ $8,6 \pm 0,31 ; \mathrm{CI}=3,7-13,5)$ or have tried drugs in the past $(\mathrm{OR}=6,0 \pm 0,28 ; \mathrm{CI}=2,9-9,2)$.

Comparative analysis within the "School students" and "Vocational students" groups (Tables 3, 4), employed and unemployed teenagers did not yield significant differences in the QLI.

Table 3

Assessment results of the quality of life in employed and unemployed school students (by SF-36)

\begin{tabular}{|c|c|c|c|c|c|c|c|c|}
\hline \multirow{2}{*}{ Observation groups } & \multicolumn{4}{|c|}{ Physical health component } & \multicolumn{4}{|c|}{ Mental health component } \\
\hline & $\mathrm{PF}$ & RFF & IP & $\mathrm{GH}$ & EA & SF & RFE & $\mathrm{MH}$ \\
\hline \multicolumn{9}{|c|}{ Girls $(n=123)$} \\
\hline All & $90,6 \pm 4,17$ & $63,4 * \pm 3,4$ & $71,6 \pm 4,17$ & $\begin{array}{c}65,6^{*} \pm 4,1 \\
7\end{array}$ & $54^{*} \pm 8,75$ & $\begin{array}{c}71,4 * \pm 3,4 \\
4\end{array}$ & $\begin{array}{c}56,6^{*} \pm 4,1 \\
7\end{array}$ & $\begin{array}{c}58,7 * \pm 4,4 \\
8\end{array}$ \\
\hline Employed (49) & $90 \pm 5,38$ & $61,2 \pm 3,91$ & $66,1 \pm 2,78$ & $62,3 \pm 4,76$ & $49,3 \pm 4,76$ & $69,1 \pm 2,78$ & $54,4 \pm 5,47$ & $53,2 \pm 3,91$ \\
\hline Unemployed $(\mathrm{N}=74)$ & $91+6,49$ & $64,9 \pm 6,49$ & $75,2 \pm 3,18$ & $67,8 \pm 6,16$ & $57,1 \pm 2,26$ & $73 \pm 10,07$ & $58,1 \pm 2,26$ & $62,4+4,45$ \\
\hline \multicolumn{9}{|c|}{ Boys $(n=83)$} \\
\hline All & $93,6 \pm 5,09$ & $82,2 \pm 3,0$ & $77,3 \pm 3,65$ & $73,6 \pm 5,09$ & $63 \pm 10,34$ & $79,8 \pm 5,81$ & $71,9 \pm 6,31$ & $69,4 \pm 4,2$ \\
\hline Employed $(\mathrm{N}=44)$ & $91,6 \pm 7,0$ & $85,8 \pm 8,0$ & $79,2 \pm 4,13$ & $74,3 \pm 5,03$ & $66+13,96$ & $81 \pm 11,56$ & $75,8 \pm 8,0$ & $70,1 \pm 2,93$ \\
\hline Unemployed $(\mathrm{N}=39)$ & $95,9 \pm 8,96$ & $78,2 \pm 4,38$ & $75,1+3,12$ & $72,8 \pm 8,5$ & $59,6 \pm 7,44$ & $78, \overline{5} \pm 6,83$ & $67,5 \pm 6,83$ & $68,7 \pm 7,99$ \\
\hline
\end{tabular}

$\mathrm{N}$ o t e s: * differences are significant for the same indicators by Student's criterion.

Table 4

Assessment results of the quality of life in employed and unemployed vocational students (by SF-36)

\begin{tabular}{|c|c|c|c|c|c|c|c|c|}
\hline \multirow{2}{*}{ Observation groups } & \multicolumn{3}{|c|}{ Physical health component } & \multicolumn{3}{c|}{ Mental health component } \\
\cline { 2 - 9 } & PF & RFF & IP & GH & EA & SF & RFE & MH \\
\hline All (N = 87) & $74,4 \pm 3,62$ & $71,9 \pm 5,29$ & $75,5 \pm 4,03$ & $63,1 \pm 1,84$ & $56,7 \pm 4,72$ & $72,4 \pm 3,62$ & $66,0 \pm 8,76$ & $59,6 \pm 4,39$ \\
\hline Employed (N=31) & $81,0 \pm 13,26$ & $63,7 \pm 8,62$ & $67,6 \pm 8,02$ & $63,8 \pm 9,17$ & $55,2 \pm 4,73$ & $73,0 \pm 15,0$ & $60,2 \pm 4,73$ & $58,7 \pm 8,62$ \\
\hline Unemployed (N=56) & $77,9 \pm 6,93$ & $71,0 \pm 10,99$ & $73,4 \pm 4,75$ & $62,6 \pm 5,75$ & $57,5 \pm 5,28$ & $75,0 \pm 10,49$ & $59,5 \pm 5,28$ & $61,9 \pm 6,93$ \\
\hline All (N = 89) & $75,3 \pm 3,11$ & $78,7 \pm 4,65$ & $76,9 \pm 5,21$ & $71,9 \pm 5,21$ & $68,2 \pm 2,55$ & $77,4 \pm 3,57$ & $77,2 \pm 2,55$ & $72,6 \pm 4,33$ \\
\hline Employed (N=54) & $75,0 \pm 10,72$ & $72,7 \pm 6,31$ & $75,0 \pm 10,72$ & $71,7 \pm 6,31$ & $67,8 \pm 6,71$ & $75,7 \pm 6,31$ & $77,2 \pm 3,46$ & $73,7 \pm 6,31$ \\
\hline Unemployed (N=35) & $75,9 \pm 9,05$ & $87,9 \pm 9,05$ & $79,7 \pm 8,07$ & $72,2 \pm 4,43$ & $68,9 \pm 9,05$ & $80,0 \pm 12,65$ & $77,1 \pm 3,15$ & $71,0 \pm 14,35$ \\
\hline
\end{tabular}

$\mathrm{N}$ o t e s: * differences are significant for the same indicators by Student's criterion

Comparative analysis of the employed school students and vocational students showed that the $\mathrm{RF}$ indicator of employed school students is 1.18 times higher than of employed vocational students. A similar comparison of the unemployed teenagers showed that the indicator is 1.2 times higher among school students. The difference is likely to be determined by more unfavorable labor conditions of employed vocational students, and a lower quality of life of vocational students in comparison with school students.

Similar results were obtained during the comparative analysis within the "Boys" and "Girls" subgroups. However, differences between the employed and unemployed male vocational students were rather significant. It was revealed that unemployed male students had a higher (by 1.2 
times) role functioning indicator associated with the physical condition (RFP).

It is evident that the quality of life in vocational students is affected by the labor conditions (their jobs often involve physical stress). Overall, the labor conditions of vocational students are worse than those of school students. For this reason, employed and unemployed school students do not have significant differences between the same indicators. The differences confirm that the quality of life of school students is higher than that of vocational students regardless extracurricular activities.

Comparative analysis of the life quality indicators within the groups of employed and unemployed school and vocational students showed that:

- employed girls (at schools and vocational institutions) do not have significant differences in the quality of life which is likely explained by the absence of heavy-duty jobs performed by the girls from both educational institutions;

- The PF and RFP indicators in employed males are higher in school students (by 1.22 and 1.18 times respectively);

- There is a significant difference in the PF indicators between the unemployed male school and vocational students (this indicator is 1.26 times is school students);

Most differences were found during the comparative analysis of the "Boys" and "Girls" groups. For example, female school students were found to have a lower quality of life as compared to men: the RP indicator in girls was 1.3 times lower. The mental health indicators (everyday activity, social functioning, role functioning associated with the social functioning, role functioning associated with emotional functioning, and mental health) were lower in girls than in boys (EAA - by 1,17 times, SF - by 1,12 , RFE - by $1,27, \mathrm{MH}$ - by 1,18 times. Girls from the "Vocational students" group had the lowest role functioning indicators associated with the physical condition (PF) and general health indicators $(\mathrm{GH})$; $\mathrm{EF}, \mathrm{RF}$, and $\mathrm{MH}$ (respectively by 1,$15 ; 1,14 ; 1,2 ; 1,29 ; 1,19$ times lower that in males). The group of employed female school students had the lowest indicators of RPF, IP, GH,
RFE, and Mental health (respectively by 1,$4 ; 1,2$; 1,$19 ; 1,34 ; 1,39 ; 1,32$ times lower than in men. Among vocational students, girls had lower RFP (by 1.28 times) and $\mathrm{MH}$ (by 1.25 times) indicators as compared to boys. Unemployed female school students had a lower RFP (by 1.2 times) indicator as compared to male students. Unemployed female vocational students had lower RFP and RFE (by 1.24 and 1.3 times lower) indicators.

Overall, girls were found to take better care of their health. They respond affirmatively to the question about the diagnosed chronic illnesses more frequently than boys: $31,7 \%$ of female school students and $28,9 \%$ of male school students had chronic illnesses $(\mathrm{OR}=1,1 \pm 0,46 ; \mathrm{CI}=0,1-2,2)$ while at vocational institutions the figures totaled $28,7 \%$ for female students and $21,3 \%$ for male vocational students $(\mathrm{OR}=1,5 \pm 0,43 ; \mathrm{CI}=0,2-2,7)$ which could be explained by more frequent doctor's visits among girls.

Conclusions. The results obtained from the comparative analysis of school students and vocational students pointed to the fact that vocational students had a lower quality of life regardless their work experience. The hypothesis about the negative impact of work on the teenage lifestyle was confirmed [9]: there were more smokers and alcohol consumers among the employed rather than the unemployed students. Alcohol consumption was found to be more common among girls especially those who had a job. This could probably be the reason why they admitted to be in worse health. Dietary issues were found to be more common among employed girls. Such behavioral patterns could be explained by the change in the social environment surrounding the teenagers, lack of consistent habits of a healthy lifestyle, and ability to confront the adults.

Teenage girls were found to be more exposed to hazardous factors as compared to boys. The impact of additional workload and associated increase in the prevalence of harmful habits had a major effect on them.

The obtained data could be used to develop programs aimed to improve the quality of teenage life accounting for the surrounding learning and workplace environment.

\section{References}

1. Baranov A. A., Kuchma V. R., Suhareva L. M. Sostojanie zdorov'ja sovremennyh detej i podrostkov i rol' mediko-social'nyh faktorov $\mathrm{v}$ ego formirovanii [State of health of modern children and teenagers and role of medico-social factors in its formation]. Vestnik RAMN, 2009, no. 5, pp. 6-11. (in Russian). 
2. Kuchma V. R., Suhareva L. M., Rapoport I. K. Izmenenie pokazatelej zabolevaemosti shkol'nikov v processe zavershenija obshhego obrazovanija. Materialy I Kongressa Rossijskogo obshhestva shkol'noj i universitetskoj mediciny i zdorov'ja [Change of indicators of incidence of school students in the course of termination of general education. Materials of the Congress I of the Russian society of school and university medicine and health]. - Moscow, 2008, pp. 94-95. (in Russian).

3. Nesteruk A. V., Shubochkina E. I., Lucenko O. A., Alekseeva E. A. Sovershenstvovanie podhodov k ocenke sanjepidblagopoluchija organizacii professional'nogo obrazovanija pri obuchenii podrostkov [Improved approaches to assessing san epidemiological welfare organization of vocational education in teaching teenagers]. Zdorov'e naselenija i sreda obitanija, 2014, no. 2, pp. 36-39. (in Russian).

4. Shubochkina E.I., Lucenko O.A., Alekseeva E.A. Gigienicheskaja ocenka vlijanija osnovnyh markernyh pokazatelej uchebnoj sredy uchrezhdenij nachal'nogo professional'nogo obrazovanija g. Pskova na kachestvo zhizni podrostkov. [Hygienic assessment of influence of the main marker indicators of the educational environment establishments of primary professional education of Pskov on quality of teenagers life]. Aktual'nye napravlenija razvitija social'no-gigienicheskogo monitoringa i analiza riska zdorov'ju: materialy Vserossijskoj nauchnoprakticheskoj konferencii s mezhdunarodnym uchastiem, Perm': Knizhnyj format, 2013, pp. 333-337. (in Russian).

5. Shubochkina E. I. Gigienicheskaja ocenka i normativnye velichiny pokazatelej kachestva zhizni podrostkov, obuchajushhihsja $\mathrm{v}$ raznyh tipah obrazovatel'nyh uchrezhdenij, po dannym oprosnika MOS SF-36. Metodicheskie rekomendacii [Hygienic assessment and standard sizes of indicators of life quality of the teenagers who study in different types of educational institutions according to MOS SF-36 questionnaire. Methodical recommendations]. Nauchnyj centr zdorov'ja detej RAMN (Shubochkina E.I., Molchanova S.S., Ibragimova E.M, Ivanov V.Ju.), GOU VPO Omskaja GMA (Blinova E.G., Novikova I.I.), GOU VPO Sankt-Peterburgskaja GMA im. Mechnikova I.I. (Janushanec O.I.), GOU VPO Smolenskaja GMA (Shestakova V.N.), Upravlenie Rospotrebnadzora po Pskovskoj oblasti (Lucenko O.A, Alekseeva E.A.). Odobreny Plenumom Nauchnogo soveta po gigiene i ohrane zdorov'ja detej i podrostkov 3 oktjabrja 2012 g. (protokol № 14), Pskov, 2012, 378 p. (in Russian).

6. Shubochkina E. I., Ivanov V. Ju. Pravo detej na bezopasnyj trud - zakonodatel'stvo i real'naja praktika [The right of children for safe work - the legislation and real practice]. Prava rebenka, 2009, no. 1, pp. 12-15. (in Russian).

7. Shubochkina E.I., Molchanova S.S, Kulikova A.V. Kachestvo zhizni i problemy formirovanija zdorov'ja uchashhihsja uchebnyh zavedenij nachal'nogo professional'nogo obrazovanija [Quality of life and problem of health formation of pupils of educational institutions of primary professional education]. Vestnik RAMN, 2009, no. 5, pp. 37-40. (in Russian).

8. Ware J.E., SherburN, C.D. The MOS 36-item short-form health survey (SF-36). Conceptual framework and item selection. Med. Care, 1992, vol. 30, pp. 437-483. 